\title{
Some Aspects of Reproduction in Amblypharyngodon mola from Sylhet, Northeast Bangladesh
}

\author{
Mohammad Amzad Hossain ${ }^{1}$ (i)
}

Cite this article as: Hossain, M.A. (2021). Some aspects of reproduction in Amblypharyngodon mola from sylhet, Northeast Bangladesh. Aquatic Sciences and Engineering, 36(3), 140-145.

ORCID IDs of the author:

M.A.H. 0000-0001-9219-3628

1 Department of Fish Biology and Genetics, Sylhet Agricultural University, Bangladesh

Submitted:

11.01.2021

Revision Requested:

28.02.2021

Last Revision Received:

03.03.2021

Accepted:

03.03.2021

Online Published:

13.04.2021

Correspondence:

Mohammad Amzad Hossain

E-mail:

mamzad.fbg@sau.ac.bd

(c) Copyright 2021 The Author(s)

Available online at

https://dergipark.org.tr/ase

\begin{abstract}
The mola carplet, Amblypharyngodon mola (Hamilton, 1822) is the most common small indigenous freshwater fish species in Bangladesh. The precise information addressing the reproduction in this species including breeding peak, ovarian histology, morphometry, and sex ration in nature is still insufficient. A one yearlong filed survey and different laboratory assays have been directed to disclose some key features of reproduction in female A. mola from wetland reservoirs in the greater Sylhet region in Bangladesh. The total length and the body weight have shown a strong correlation with gonad weight, occupying statistical $r^{2}$ values of 0.89 and 0.91 , respectively. However, a Chi-square test at $\mathrm{P}<0.05$ reported no significant deviation in sex ration of the wetland's stock. The maximum fecundity has been reported during the month of May as 12569+620 while the lowest is during the month of July as $9377+455$. The highest values for gonadosomatic index have been reported in May while the lowest is in January with another peak in November. The histological study of ovarian cells resulted in the characterization of oocytes, previtellogenic oocytes, vitellogenic oocytes, perinuclear oocytes, and mature cells with yolk mass.
\end{abstract}

Keywords: Amblypharyngodon mola, sex ration, GSI, fecundity, morphometric regression analysis, gonadal histology

\section{INTRODUCTION}

The mola, Amblypharyngodon mola is one of the most popular small indigenous fish (SIF) species in Bangladesh, which occupy almost all of the shallow freshwater habitats (Mondal \& Kaviraj, 2013; Mondal et al., 2019). This fish has drawn significant commercial and cultural value due to its premium nutritional value (Abdulla et al., 2004; Alam et al., 2004; Shikha et al., 2019) and current adoption as ornamental fish in aquarium (Gupta \& Banerjee, 2015). Currently this species is also subjected to coculturation with other cyprinid fish or in traditional pond culture technique to supplement domestic food supply in South Asian countries (Neetu \& Seema, 2018). This fish is considered as one of the major species to meet the rural nutrition supplement and also constitutes the principle target of small scale artisanal fishing practices in Bangladesh (Bengal et al., 2017). Rich protein contents and the abundance of micronutrients make this species one of the thriving mediators for securing poor people's nutrition and the economy as well (Ahmed et al., 2012; Hossain et al., 2017; Kohinoor et al., 1998).

Information regarding the body parameters (Khalid et al., 2020), growth factors, and different reproductive indices, i.e., hepatosomatic index, gonadosomatic index and fecundity etc. (Jabed et al., 2020; Jannatul et al., 2015; Rahman et al., 2020), serves as key indicators of reproductive progression and breeding phase of fish (Amzad et al., 2015; Mian et al., 2020; Uddin et al., 2017), which are essential for implementing fishery strategies and conservation approaches (lqbal \& Naeem, 2018; Jannatul et al., 
2015; Mian et al., 2017). Biometric features of fish are a widely accepted form of data which bears necessary information about the growth, development and stock assessment of the fish (Muchlisin et al., 2010). The major quantitative features in fish (i.e., total length, body weight, gonad weight, and fecundity) provide actual biological modelling of species in a particular geographical area (Emre, 2020; Tharwat et al., 2018). The understanding on major aspects of wild breeding biology, annual reproductive peak, breeding season, ovarian maturation phases, and fecundity will certainly help in the future management of this species (Ahamed et al., 2017; Uddin et al., 2017).

\section{MATERIALS AND METHODS}

\section{Study area and duration}

Fresh and live random samples of $A$. mola have been collected from different fisher landing stations and local markets of the Greater Sylhet region of Bangladesh. They were transported in insulated ice boxes or in oval fiberglass tanks to bring into the Fish Biology and Genetics laboratory of Sylhet Agricultural University, Bangladesh. This research continued for a full-length year from July 2019 to June 2020.

\section{Recording morphometric data}

Shortly after bringing them back to the laboratory, all the fish were washed well with rinsing freshwater and placed on thick tissue towels to reduce the access of water and mucous content within them. Then, the total length and weight of each fish was calculated by using scale (a mm stainless-steel scale attached on a specially designed wooden structure) and electric balance (Ohaus corp. Pine Brook, NJ USA), respectively. Sexual recognition of each fish was confirmed by following the dissection of their gonad, which was weighted and recorded immediately.

Measurement of gonadosomatic index (GSI) and Fecundity The value of gonadosomatic index for each fish was calculated by using the below formula (Brooks et al., 1997)

Gonadosomatic index (GSI) $=($ Weight of gonad (g)/ Total body weight (g)) $\times 100$

Fishes collected during the early to late monsoon season was subjected to the calculation of fecundity. Gravid female fish were selected for fecundity, and Gilson's fluid was used to lessen the oocytes. Finally, absolute fecundity was calculated by using the description of Rahman \& Samat, (2020).

The fecundity, $F=n \times G / g$, where " $n$ " denoted the average number of eggs counted in sub-sample, " $G$ " is net weight of the gonads, and " $g$ " is the weight of the sub-sample.

\section{Histology of gonad}

The samples from the ovaries were chopped into small pieces and preserved in neutral buffered formalin. The standard protocol for gonad histology described by Van-Dyk \& Pieterse, (2008) was followed for the preparation of histology slides. Tissues were embedded and infiltrated in Paraffin, and the resulting blocks were formatted into 3 micrometer slides. Finally, hematoxylin-Eosin staining accompanied the samples to view the cell with a Zeiss microscope (software version 3.0 pro).

\section{Data analysis}

The raw data were recorded on excel sheet before further analysis. Data were analyzed by using IBM SPSS Statistics v26 and a one-way ANOVA was tested at $\mathrm{P}<0.05$ to measure the difference between mean values.

\section{RESULTS AND DISCUSSIONS}

The ratio between female and male fishes of $A$. mola in the wild natural wetland of the Greater Sylhet region does not vary significantly between months. However, the lowest male to female ratio was accounted in May (1:0.6), followed by January, July, and November (1:0.7), and by March, August, September, and December (1:0.8) (table 1). In contrast, the maximum value for the male to female ratio was observed during the month of October (1:2.03), followed by February, June (1:1.5) and April (1:1.3) (Table 1).

Table 1. Analysis (Chi-square test, $\mathrm{P}<0.05)$ of sex ration of A. mola

\begin{tabular}{|c|c|c|c|c|c|c|c|}
\hline \multirow{2}{*}{ Month } & \multirow{2}{*}{$\begin{array}{c}\text { Total } \\
\text { Sample }\end{array}$} & \multicolumn{2}{|c|}{ Female } & \multicolumn{2}{|c|}{ Male } & \multirow{2}{*}{$\begin{array}{c}\chi^{2-} \\
\text { value }\end{array}$} & \multirow{2}{*}{$\begin{array}{l}\text { Ration } \\
\text { (M: F) }\end{array}$} \\
\hline & & No. & $\%$ & No. & $\%$ & & \\
\hline Jan & 20 & 12 & 60 & 08 & 40 & 1.2 & 01:00.7 \\
\hline Feb & 25 & 10 & 40 & 15 & 60 & 1.2 & 01:01.5 \\
\hline Mar & 30 & 16 & 53 & 14 & 47 & 0.14 & 01:00.8 \\
\hline Apr & 30 & 13 & 43 & 17 & 57 & 0.54 & 01:01.3 \\
\hline May & 30 & 19 & 63 & 11 & 37 & 2.13 & 01:00.6 \\
\hline Jun & 25 & 10 & 40 & 15 & 60 & 1.2 & 01:01.5 \\
\hline Jul & 20 & 12 & 60 & 08 & 40 & 1.2 & 01:00.7 \\
\hline Aug & 30 & 16 & 53 & 14 & 47 & 0.13 & 01:00.8 \\
\hline Sep & 30 & 16 & 53 & 14 & 47 & 0.13 & 01:00.8 \\
\hline Oct & 30 & 10 & 33 & 20 & 67 & 3.33 & $01: 2.03$ \\
\hline Nov & 30 & 17 & 57 & 13 & 43 & 0.53 & 01:00.7 \\
\hline Dec & 30 & 16 & 53 & 14 & 47 & 0.13 & $01: 00.8$ \\
\hline
\end{tabular}

The body weight $(\mathrm{mg})$ data was plotted against the correspondent of total length $(\mathrm{cm})$ data to disclose the regression analysis of above morphometry. The regression line shows a strong correlation between body weight and total length of $A$. mola in the natural wetlands of Northeast Bangladesh with a $r^{2}$ value of 0.89 . It shows that about 89 percent of fish showed increasing weight in relation to total length or vice versa (Figure 1). Again, fecundity was also found to have a very strong correlation with increasing body weight of fish, occupying an estimated $r^{2}$ value of 0.91, showing that large fish tend to have more fecundity than smaller ones (Figure 2.A). However, the values of the total length show very minor and nonsignificant correlations with ovarian weight (Figure 2.B). The gonadosomatic index of $A$. mola in the natural wetlands of Sylhet, Northeast Bangladesh were reported to be very distinctive on a month-wise distribution. The highest GSI value was recorded in May (16.66) and then fell to 12.58 in June (Figure 3). The two peaks in GSI value were noticed once in May 


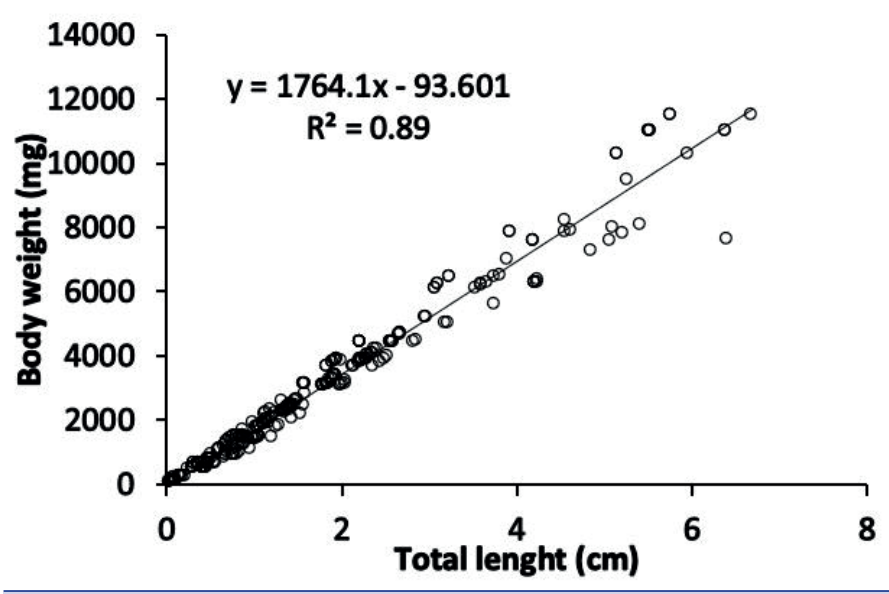

Figure 1. Length weight relationship of A. mola in Sylhet, Northeast Bangladesh.
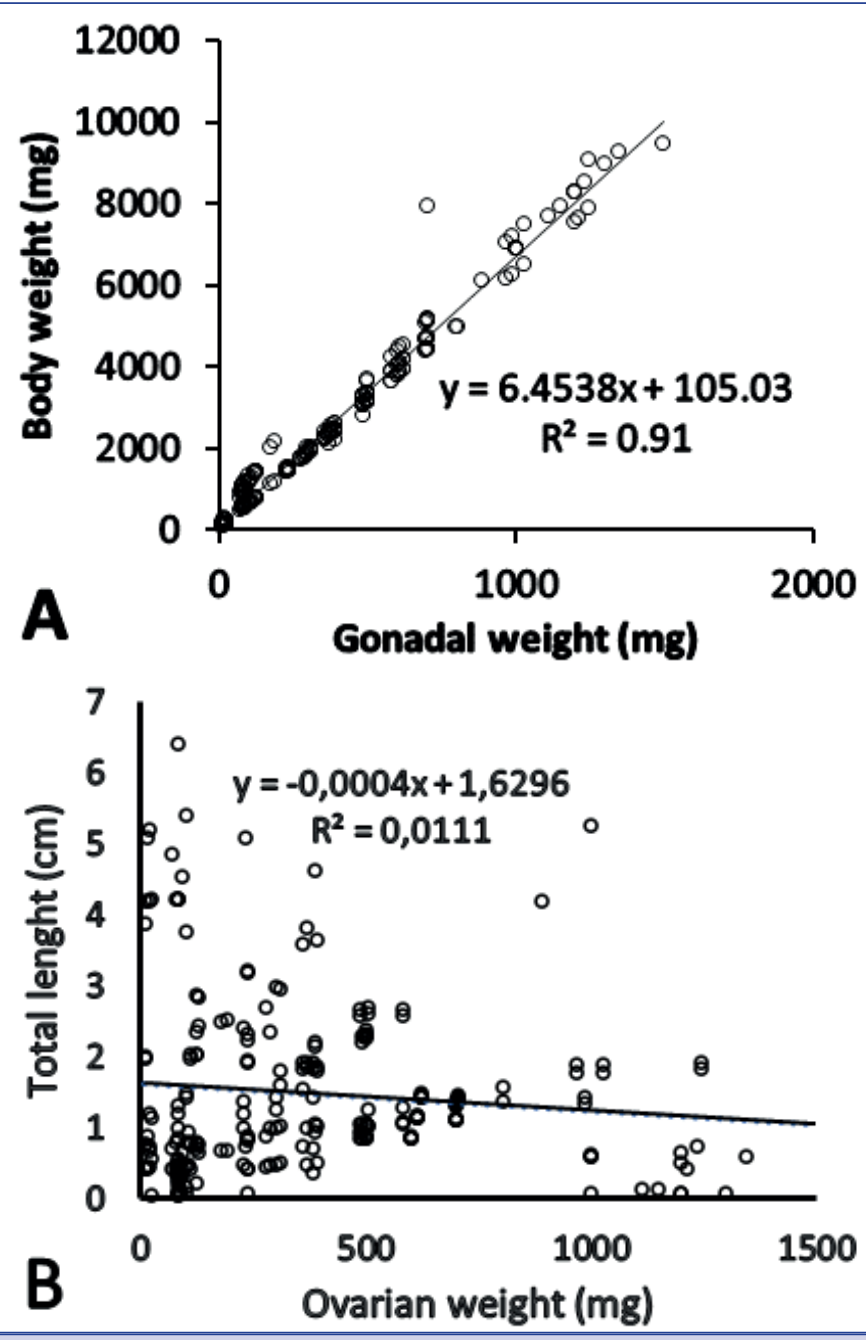

Figure 2. Relation between $A$. body weight and gonadal weight, B. total length and gonadal weight of $A$. mola in Sylhet, Northeast Bangladesh.

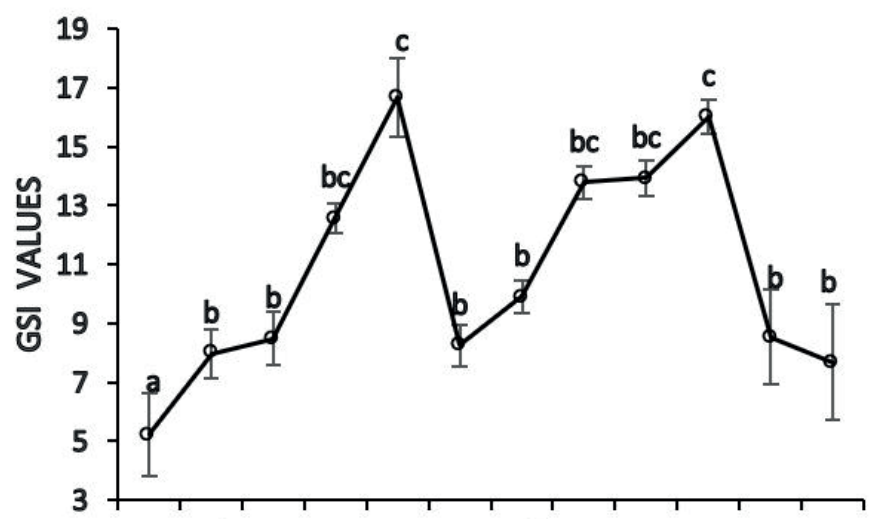

Jan Feb Mar Apr May Jun Jul Aug Sep Oct Nov Dec

Figure 3. Gonado-somatic index of female A. mola.

and another in November 8.54 (Figure 3). The female A. mola in the natural wetlands of Sylhet, Northeast Bangladesh have been reported as an intermediate fecundated species. The highest fecundity was observed during the month of May as 125689+620, followed by 11172+160 in August and 10531+305 in June (Figure 4). However, the lowest fecundity was accounted during July $9377+455$, followed by $9947+55$ in September (Figure 4).

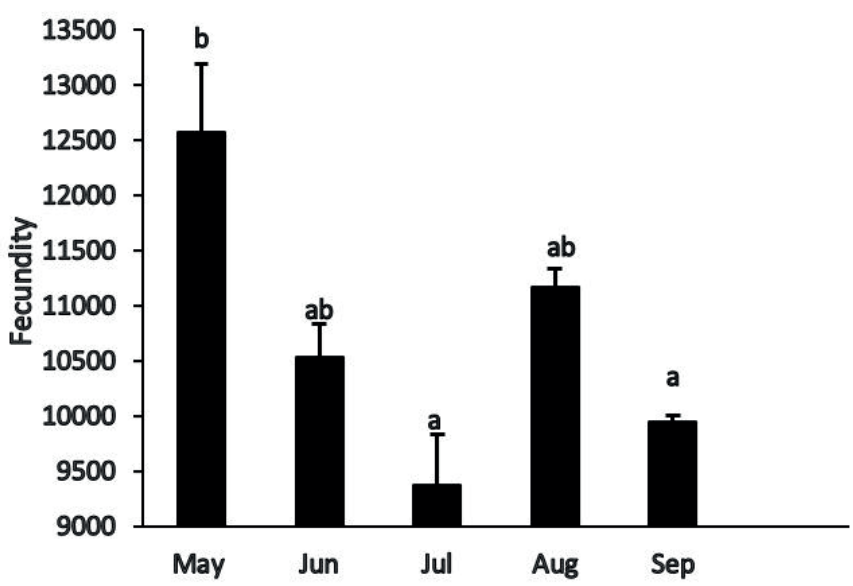

Figure 4. Variation in fecundity of Amblypharyngodon mola in Sylhet, Northeast Bangladesh.

The histological analysis of ovarian tissue resulted in the occurrence of oocytes and pre-vitellogenic oocytes as the initial phase of gonadal maturation (Figure 5.A). At the end of primary development phase, the nuclear mass of the cell tends to migrate toward the periphery, termed as perinuclear oocytes (Figure 5.B). Mature vitellogenin oocytes are characterized by the presence of yolk globules and yolk vesicles in the cell (Figure 5.C).

The sex ratio for a particular of the species would be different in response to habitat, fishing strategies, and harvesting method also (Oh et al., 2008). A study by Das et al., (2018) recorded sex ration of 1 : 2.05 for $A$. mola in Dekar Haor of Sunamganj, Bangladesh while a 1:3.04 male to female ratio was reported by Gupta 


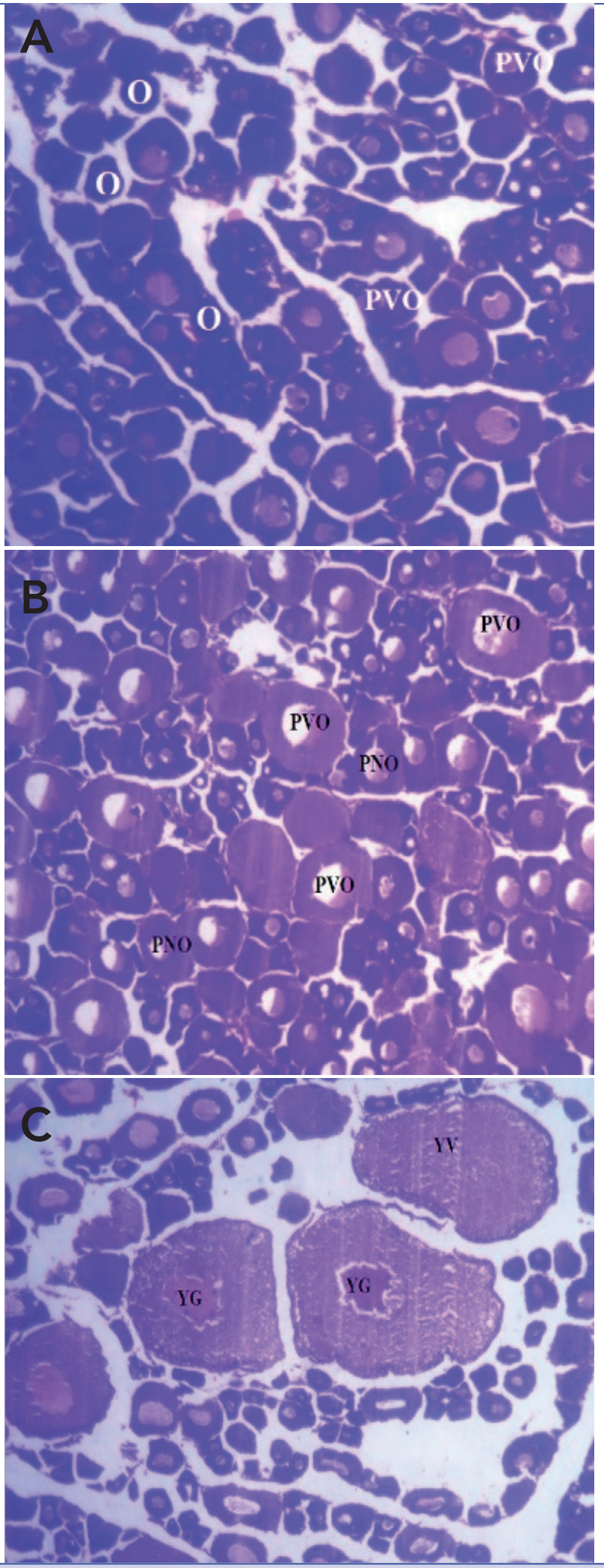

Figure 5. Different stages of development in ovarian cell of $A$. mola (O-oocytes stage, PVO-previtellogenic stage, PNO-perinuclear oocytes, YV-yolk vesicle, YG-yolk globules.
\& Banerjee (2013) for the natural wetland of Baruipur, West Bengal, and 1.00:2.078 was recorded by Azadi \& Mamun (2004) at the Kaptai Reservoir in Bangladesh. Current research is supportive of the previous study by Ahmed, et al., (2017), who had reported male to female ratio ranges between 1:1.14 to 1.32 in the Payra River of southern Bangladesh.

Morphometric studies of fish provide beneficial information towards the better understanding of the maturity and life history of particular species (Hossain et al., 2006). Previous research by Gupta $\&$ Banerjee (2015) observed a regression correlation value of 0.913 for female $A$. mola it freshwater from West Bengal, India, while Nawer et al. (2018) reported a $r^{2}$ value of 0.93-0.96 for the same species in the Ganges River, Northwestern Bangladesh. All the above studies closely stand with the present findings for $A$. mola in the Greater Sylhet region, Bangladesh. The fecundity of fish was reported to be boosted with fish size (Jannatul et al., 2015); the relation between fecundity and body weight might have shifted drastically during the onset of breeding season due to dramatic modification of egg size (Rai et al., 2018). A positive correlation between fecundity and body weight was reported for several, i.e., $r^{2}=0.77$ for Xenontedon cancila from Assam, India (Borthakur, 2018), $r^{2}=$ 0.75 for Mystus cavasius (Hamilton) from Brahmaputra and Kongsa river, Bangladesh (Islam \& Das, 2006), ${ }^{2}=0.87$ for Oreochromis Niloticus from Balochistan (Kausar et al., 2019), and $r^{2}=0.79$ for cyprinid fish Labeo calbasu at Faridpur, Bangladesh (Kabir \& Quddus, 2015). The present study also revealed a similar trend of morphometric correlation, and slight variations are raised because of differences in study location, season, and sampling strategies.

The values of gonadosomatic indices act as potential marker for addressing the gonadal development stage, maturity, and breeding peaks of individual fish species (Hasan et al., 2018). Gupta \& Banerjee (2013) had identified two distinguished GSI peaks for A. mola in west Bengal, India, one in June and another one October, and reached the second peak in November while a single peak in July had been observed by Mondal \& Kaviraj, (2013) in the floodplain lakes of India. The lowest GSI value had been observed in January while highest value was in June for the same species from Bengal, India (Pal \& Mahapatra, 2016). Two peaks in June and November and the lowest value in January had been documented in South Bengal, India (Pal and Mahapatra, 2016). Multiple peaks revealed that this species might spawn several times within year. The deviation of peaks in the current research might vary due to the study's geography and sampling strategies. The fecundity of a species depends upon a variety of intrinsic factors, environmental features, and nutritional properties of the diet (Alam et al., 2004; Kohinoor et al., 1998; Mian et al., 2020), and accurate knowledge in fish fecundity helps in regulating harvesting quotas and also provides key roles in aquaculture and fishery management (Kant et al., 2016; Tracey et al., 2007). The fecundity of mature female of $A$. mola ranged between 3785 to 12590 oocytes in floodplain water of India (Mondal \& Kaviraj, 2013), 1,548-4,020 oocytes in the natural waters of South Myanmar (Kulabtong, 2016), varied between 1,280-13,679 in the Kaptai Reservoir in Bangladesh (Azadi \& Mamun, 2004), and fluctuated between 1652 to 15,985 in the Ganges River of Bangladesh (Rahman et al., 2018). The findings of present research are also strongly supported by above previous results. 
Ovarian histology provides essential data for predicting the reproductive success and peak in several fish species (Alonso-Fernández et al., 2011; Emam \& Abughrien, 2014; Jabed et al., 2020). Previous studies on different fish species revealed a characterization of oocytes and previtellogenic oocytes during the initiation of reproductive peak (Guraya et al., 1975; Viana et al., 2018). As the development process goes onward, the size of ovum and yolk globules increases (Murata et al., 2014; Quagio-Grassiotto et al., 2014). However, the simultaneous occurrence of different development stages also indicate the nature of several spawning peaks in this fish (Amzad et al., 2015; Jabed et al., 2020), which is also aligned with their multiple peaks in GSI values.

\section{CONCLUSIONS AND RECOMMENDATIONS}

This research has disclosed a set of necessary information regarding the reproductive aspects of $A$. mola from the natural wetlands of the Greater Sylhet region of Bangladesh. The above information might be used in the aquaculture development, wild stock management, and conservation of this fish in Bangladesh. However, broad studies with the collection of samples from different areas within the country would reflect actual trends of the reproduction in this fish.

Conflict of interests: No conflict of interest has been generated on this research work.

Ethics committee approval: The research has complied and essentially approved with all regional, national, and institutional ethical clearance.

\section{Funding: -}

\section{Acknowledgments: -}

\section{Disclosure: -}

\section{REFERENCES}

Abdulla, Al., Mondal, S., Wahab, A., \& Barm, B. K. (2004). Food and feeding habits of Amblypharyngodon mola (Hamilton) from Kaptai Reservoir, Bangladesh. Pakistan Journal of Biological Sciences, 7(4), 584-588. [CrossRef]

Ahamed, F., Ahmed, Z. F., Hossain, M. Y., \& Ohtomi, J. (2017). Growth and longevity of the mola carplet Amblypharyngodon mola (Cyprinidae) in the Payra River, southern Bangladesh. Egyptian Journal of Aquatic Research, 43(4), 291-295. [CrossRef]

Ahamed, F., Saha, N., Ara, M. G., Ahmed, F., \& Hossain, Y. (2017). Biological aspects of the mola carplet Amblypharyngodon mola (Cyprinidae) in the Payra. International Journal of Fisheries and Aquatic Studies, 5(4), 336-339. [CrossRef]

Ahmed, Z., Hossain, Y., \& Ohtomi, J. (2012). Modeling the growth of Silver hatchet chela Chela cachius (Cyprinidae) from the old Brahmaputra River in Bangladesh Using Multiple Functions. Zoological Studies, 51(3), 336-344.

Alam, M. J., Dewan, S., Rahman, M. R., Kunda, M., Khaleque, M.A., \& Kader, M.A. (2004). Study on the cultural suitability of Amblypharyngodon mola with Barbodes gonionotus and Cyprinus carpio in a farmer's rice fields. Pakistan Journal of Biological Sciences, 7(7), 1242-1248. [CrossRef]

Alonso-Fernández, A., Alós, J., Grau, A., Domínguez-Petit, R., \& Saborido-Rey, F. (2011). The use of histological techniques to study the reproductive biology of the hermaphroditic Mediterranean fishes Coris julis, Serranus scriba, and Diplodus annularis. Marine and Coastal Fisheries, 3(1), 145-159. [CrossRef]

Amzad, H. M., Sohel, M., Mariya, A., Fazley, R. A., Marine, S. S., Rahman, M. A., Mahbub, I. M., Jakiul, I. M., Hassan, M. M., \& Hossain, M. M. (2015). Ovarian biology of spotted snakehead (Channa punctatus) from natural wetlands of Sylhet, Bangladesh. Annals of Veterinary and Animal Science, 2(3), 64-76. http://naturepub.org/index.php/ journal/navas

Azadi, M. A., \& Mamun, A. (2004). Reproductive biology of the Cyprinid, Amblypharyngodon mola (Hamilton) from the Kaptai Reservoir, Bangladesh. Pakistan Journal of Biological Sciences, 7(10), 17271729. [CrossRef]

Bengal, W., Saha, D., Pal, S., Rahaman, H. S., Nandy, G., Chakraborty, A., Aditya, G., \& Aditya, G. (2017). Exploitation pattern of small indigenous fish species: observations from fish markets of rural. AACL Bioflux, 10(2), 779-786. http://www.bioflux.com.ro/aacl

Borthakur, D. M. K. (2018). Study of gonadosomatic index and fecundity of freshwater fish Xenontedon cancila. Journal of Entomology and Zoology Studies, 6(3), 42-46. http://www.entomoljournal.com/ archives $/$ ?year $=2018 \&$ vol=6\&issue $=3 \&$ Articleld $=3548$

Brooks, S., Tyler, C. R., \& Sumpter, J. P. (1997). Egg quality in fish: what makes a good egg? Reviews in Fish Biology and Fisheries, 7(4),387416. [CrossRef]

Das, P. R., Uddin, M. S., Islam, M. S., Biswas, M., \& Mia, M. R. (2018). Length-weight relationship and sex ratio of Amblypharyngodon mola in Dekar haor of Sunamganj, Bangladesh. Journal of Asiatic Society, 44(2), 185-193. [CrossRef]

Emam, M. A., \& Abughrien, B. (2014). Seasonal histological changes in gonads of the catfish (Clarias lazera). Fisheries and Aquaculture Journal, 05(01),3-6. [CrossRef]

Emre, N. (2020). Biometric relation between asteriscus otolith size and fish total length of seven cyprinid fish species from inland waters of Turkey. Turkish Journal of Fisheries and Aquatic Sciences, 20(3), $171-$ 175. [CrossRef]

Gupta, S, \& Banerjee, S. (2013). Studies on some aspects of Reproductive biology of Amblypharyngodon mola. International Research Journal of Biological Sciences, 2(2), 69-77.

Gupta, Sandipan, \& Banerjee, S. (2015). Length-weight relationship of Amblypharyngodon mola (Ham.Buch., 1822), a freshwater cyprinid fish from West Bengal, India. Zoology and Ecology, 25(1), 54-58. [CrossRef]

Guraya, S. S., Kaur, R., \& Saxena, P. K. (1975). Morphology of ovarian changes during the reproductive cycle of the fish, Mystus tengara (Ham.). Acta Anatomica, 91(2), 222-260. [CrossRef]

Hasan, T., Hossain, M. F., Mamun, M., Alam, M. J., Salam, M. A., \& Rafiquzzaman, S. M. (2018). Reproductive Biology of Puntius sophore in Bangladesh. Fishes, 3 (2). [CrossRef]

Hossain, M. A., Akter, M., \& lqbal, M. M. (2017). Diversity of fish fauna in Kusiara river (Fenchungonj Upazilla), Northeast Bangladesh. Journal of Aquaculture in the Tropics, 32(1), 1-13.

Hossain, M. Y., Ahmed, Z. F., Leunda, P. M., Roksanul Islam, A. K. M., Jasmine, S., Oscoz, J., Miranda, R., \& Ohtomi, J. (2006). Lengthweight and length-length relationships of some small indigenous fish species from the Mathabhanga River, southwestern Bangladesh. Journal of Applied Ichthyology, 22(4), 301-303. [CrossRef]

Iqbal, M. J., \& Naeem, M. (2018). Study of External morphometric variants and length-weight relationship of Labeo rohita (Hamilton-1822) fed with varying protein levels. Sarhad Journal of Agriculture, 34(4). [CrossRef]

Islam, M., \& Das, M. (2006). Fecundity of Gulsha Mystus cavasius (Hamilton) from Brahmaputra and Kongsa rivers. Journal of the Bangladesh Agricultural University, 4(2), 347-355.

Jabed, M. N., Hossain, M. A., Mian, S., Kabir, M. A., Mazumder, S. K., \& lqbal, M. M. (2020). Some aspects of reproduction in long whiskered 
catfish, Sperata aor (Hamilton 1822), from North-East Bangladesh. Aquaculture Studies, 21(2), 47-54. https://doi.org/10.4194/26186381-v21_2_01

Jannatul, H., Chandra, R. N., Jannatul, F. M., Amzad, H. M., Mehedi, H. M., Das, T. B., Sohel, M., Mahbub, I. M., Bodrul, M. M., \& Mosarof, H. M. (2015). Reproductive biology of striped snakehead (Channa striata) from natural wetlands of Sylhet, Bangladesh. Annals of Veterinary and Animal Science, 2(6), 162-169.

Kabir, M., \& Quddus, M. (2015). Fecundity and gonadosomatic index of Labeo calbasu (Hamilton) from a stocking pond of a hatchery at Faridpur, Bangladesh. Bangladesh Journal of Zoology, 41(1), 43-48. [CrossRef]

Kant, K. R., Gupta, K., \& Langer, S. (2016). Fecundity in fish Puntius sophore and relationship of fecundity with fish length, fish weight and ovary weight from Jammu water. International Journal of Fisheries and Aquaculture Sciences., 6(2), 99-110. https://www. researchgate.net/publication/334162676

Kausar, R., Sadozai, S., Achakzai, W., Yar, A. A., Tariq, N., \& Ali, H. (2019). Estimation of fecundity and gonado-somatic index of Oreochromis Niloticus (Linnaeus) from fish market of Quetta, Balochistan. Jacobs Journal of Entomology and Zoological Studies, 2(1), 1-8.

Khalid, M., Masud, S., Naeem, Z., Shahid, M. M., Naeem, A. D., Ishtiaq, A., \& Naeem, M. (2020). Length-weight and length-length relationships of farmed Catla catla during winter season from Muzaffargarh, Pakistan. Sarhad Journal of Agriculture, 36(3). [CrossRef]

Kohinoor, A. H. M., Islam, M. L., Wahab, M. A., \& Thilsted, S. H. (1998), Effect of mola (Amblypharyngodon mola Ham.) on the growth and production of carps in polyculture. Bangladesh Journal of Fisheries Research, 2(2), 119-126.

Kulabtong, S. (2016). Biological data of Burmese carplet Amblypharyngodon atkinsonii (Blyth, 1860) in South Myanmar (Cypriniformes Cyprinidae): a preliminary report. Biodiversity Journal, 7(2), 253-256.

Mian, S., Papree, S. D., Dey, T., Hossain, M. A., Iqbal, M. M., Abol-Munaf, A. B., \& Islam, M. S. (2017). Some Reproductive Aspects of Freshwater Garfish, Xenentodon cancila (Hamilton, 1822) from North-East Bangladesh. Journal of Fisheries and Aquatic Science, 12(2), 82-89. [CrossRef]

Mian, S., Shah, A. W., Hossain, M. A., Hossain, M. S., lqbal, M. M., \& Debnath, P. (2020). Reproductive Biology of Captive reared spotted Snakehead, Channa punctatus (Bloch 1793) Channidae. Bulletin of Environment, Pharmacology and Life Sciences, 9(2), 8-15.

Mondal, D. K., \& Kaviraj, A. (2013). Feeding and reproductive biology of Amblypharyngodon mola (Cyrpiniformes: Cyprinidae) from two floodplain lakes of India. International Journal of Aquatic Biology, 1(3), 125-131. https://doi.org/10.22034/ijab.v1i3.62

Mondal, S., Wahab, A., Barman, B. K., \& Hossain, M. M. (2019). Advances in Bioresearch Reproductive Biology of Flying barb, Darkina, Esomus danricus. 10(1), 68-81. https://doi.org/10.15515/abr.0976-4585.10.2.6881

Muchlisin, Z. A., Musman, M., \& Siti Azizah, M. N. (2010). Length-weight relationships and condition factors of two threatened fishes, Rasbora tawarensis and Poropuntius tawarensis, endemic to Lake Laut Tawar, Aceh Province, Indonesia. Journal of Applied Ichthyology, 26(6), 949953. [CrossRef]

Murata, K., Conte, F. S., Mclnnis, E., Fong, T. H., \& Cherr, G. N. (2014). Identification of the origin and localization of chorion (egg envelope) proteins in an ancient fish, the white sturgeon, Acipenser transmontanus. Biology of Reproduction, 90(6), 132. [CrossRef]

Nawer, F., Hossain, M. Y., Sarwar, M. G., Rahman, O., Khatun, D., Parvin, M. F., Jasmine, S., Ahmed, Z. F., Ahamed, F., \& Ohtomi, J. (2018). Growth, maturity and form factor of Mola Carplet (Amblypharyngodon mola) from the Ganges River, Northwestern Bangladesh. Jordan Journal of Biological Sciences, 11(4), 375-380.
Neetu, N., \& Seema, J. (2018). Otolith morphometry and fish length relation of Amblypharyngodon mola (Ham.) from Middle Ganga region (India). International Journal of Fisheries and Aquaculture, 10(10), 122-128. [CrossRef]

Oh, C.-W., Byun, J.-H., Choi, J. H., \& Kim, H.-W. (2008). Reproductive Biology of Pandalus gracilis Stimpson, 1860 (Decapoda, Pandalidae) in the Southeastern Coastal Waters of Korea. Crustaceana, 81(7), 797-811. [CrossRef]

Pal, M., \& Mahapatra, B. (2016). Fecundity and GSI of Mourala, Amblypharyngodon mola (Hamilton-Buchanan, 1822) from South Bengal district of West Bengal. International Journal of Fisheries and Aquatic Studies, 4(5), 47-53.

Pal, M., \& Mahapatra, B. K. (2016). Fecundity and GSI of Mourala, Amblypharyngodon mola (Hamilton-Buchanan, 1822) from South Bengal district of West Bengal. International Journal of Fisheries and Aquatic Studies, 4(5), 47-53.

Quagio-Grassiotto, I., Wildner, D. D., \& Guimarães-Bassoli, A. C. D. (2014). A cytochemical approach to describe oocyte development in the freshwater ostariophysan, Serrasalmus maculatus (Characiformes). Micron (Oxford, England: 1993), 60, 18-28. [CrossRef]

Rahman, M. A., Hossain, M. A., Ullah, M. R., \& lqbal, M. M. (2020). Reproductive biology of Gagora catfish (Arius gagora) at Meghna river system, Kushiara. International Journal of Aquatic Biology, 8(6), 383-395

Rahman, M. M., Hossain, M. Y., Tumpa, A. Sen, Hossain, M. I., Billah, M. M., \& Ohtomi, J. (2018). Size at sexual maturity and fecundity of the mola carplet Amblypharyngodon mola (Hamilton 1822) (Cyprinidae) in the Ganges River, Bangladesh. Zoology and Ecology, 28(4), 429436. [CrossRef]

Rahman, Musrafizur M, \& Samat, A. F. (2020). Reproductive cycle, sexual maturity and fecundity of Nemipterus furcosus (Valenciennes, 1830). Aquaculture and Fisheries. [CrossRef]

Rai, S., Yadav, K. K., \& Trivedi, S. P. (2018). Ovarian Impairment in Fish, Channa punctata (Bloch) on Exposure to Mercuric Chloride, Caldan $50 \mathrm{SP}$ and their Mixture. Journal of Ecophysiology and Occupational Health, 19(1\&2), 65-70. [CrossRef]

Shikha, F. H., Hossain, M. I., \& Shohan, S. (2019). Effect of low temperature on quality of Mola (Amblypharyngodon mola) fish pickle during storage and consumer preference towards. Bangladesh Journal of Fisheries Research, 31, 125-135.

Tharwat, A., Hemedan, A. A., Hassanien, A. E., \& Gabel, T. (2018). A biometric-based model for fish species classification. Fisheries Research, 204, 324-336. [CrossRef]

Tracey, S. R., Lyle, J. M., \& Haddon, M. (2007). Reproductive biology and per-recruit analyses of striped trumpeter (Latris lineata) from Tasmania, Australia: Implications for management. Fisheries Research, 84(3), 358-367. [CrossRef]

Uddin, S., Hasan, M. H., Iqbal, M. M., \& Hossain, M. A. (2017). Study on the reproductive biology of Vietnamese climbing perch (Anabas testudineus, Bloch). Punjab University Journal of Zoology, 32(1), 1-7.

Van-Dyk, J. C., \& Pieterse, G. M. (2008). A histo-morphological study of the testis of the sharptooth catfish (Clarias gariepinus) as reference for future toxicological assessments. Journal of Applied Ichthyology, 24(4), 415-422. [CrossRef]

Viana, I. K. S., Gonçalves, L. A. B., Ferreira, M. A. P., Mendes, Y. A., \& Rocha, R. M. (2018). Oocyte growth, follicular complex formation and extracellular-matrix remodeling in ovarian maturation of the imperial zebra pleco fish Hypancistrus zebra. Scientific Reports, 8(1), 13760. [CrossRef] 